\title{
DIGLOSIA
}

Terakreditasi Sinta 3 | Volume 3 | Nomor 3 | Tahun 2020 | Halaman 317-330

P-ISSN 2615-725X | E-ISSN 2615-8655

http://diglosiaunmul.com/index.php/diglosia/article/view/64

\section{MUATAN KEARIFAN LOKAL PADA BUKU BACAAN SISWA TERBITAN KEMDIKBUD}

\author{
Content of Local Wisdom in the Student Reading Books Published \\ by the Ministry of Education and Culture
}

\author{
Aisyah Nur Fadhilah ${ }^{1, *}$ dan Laili Etika Rahmawati ${ }^{2}$ \\ ${ }^{1,2}$ Universitas Muhammadiyah Surakarta \\ 1,* Pos-el korespondensi: aisyahf560@gmail.com \\ ${ }^{2}$ Pos-el: laili.rahmawati@ums.ac.id
}

\begin{abstract}
This study aims to identify the content of local wisdom in the student reading books published by the Ministry of Education and Culture. This type of research is a qualitative descriptive study. The object of research is the content of local wisdom in the student reading books published by the Ministry of Education and Culture entitled "Kenara Anak Suku Gayo" and "Kain Kulit Kayu Dei". The data from this study are student reading books published by the Ministry of Education and Culture which contain local wisdom. The data source in this research is an archive or document in the form of a student reading book published by the Ministry of Education and Culture which contains local wisdom. The data collection technique uses the technique of listening and note taking, the researcher first reads the reading book "Kenara Anak Suku Gayo" and "Kain Kulit Kayu Dei" published by the Ministry of Education and Culture to carefully determine the local wisdom content, then record thoroughly and analyze the reading into the wisdom content. local. Data analysis techniques using flow analysis. The results showed that the reading book. "Kenara Anak Suku Gayo" contained five contents of local wisdom including: (1) culture, (2) norms, (3) ethics, (4) beliefs, and (5) customs. While the reading book "Kain Kulit Kayn Dei" there are only three contents of local wisdom including: (1) culture, (2) beliefs, and (3) customs.
\end{abstract}

Keywords: local wisdom, reading books, Ministry of Education and Culture

\begin{abstract}
Abstrak: Penelitian ini bertujuan untuk mengidentifikasi muatan kearifan lokal pada buku bacaan siswa terbitan Kemdikbud. Jenis penelitian ini adalah penelitian deskriptif kualitatif. Objek penelitian, yaitu muatan kearifan lokal pada buku bacaan siswa terbitan Kemdikbud yang berjudul Kenara Anak Suku Gayo dan Kain Kulit Kayu Dei. Data dari penelitian ini adalah buku bacaan siswa terbitan Kemdikbud yang memuat kearifan lokal. Sumber data dalam penelitian adalah arsip atau dokumen berupa buku bacaan siswa terbitan Kemdikbud yang memuat kearifan lokal. Teknik pengumpulan data menggunakan teknik simak dan catat, yakni peneliti terlebih dahulu membaca buku bacaan Kenara Anak Suku Gayo dan Kain Kulit Kayu Dei terbitan Kemdikbud secara teliti untuk menentukan muatan kearifan lokal, kemudian mencatat secara utuh lalu menganalisis bacaan ke dalam muatan kearifan lokal. Teknik analisis data menggunakan analisis mengalir. Hasil penelitian menunjukkan bahwa buku bacaan Kenara Anak Suku Gayo terdapat lima muatan kearifan lokal: (1) budaya, (2) norma, (3) etika, (4) kepercayaan, dan (5) adat istiadat. Sedangkan buku bacaan Kain Kulit Kayu Dei hanya terdapat tiga muatan kearifan lokal: (1) budaya, (2) kepercayaan, dan (3) adat istiadat.
\end{abstract}

Kata kunci: kearifan lokal, buku bacaan, Kemdikbud

\section{A. PENDAHULUAN}

Buku bacaan siswa perlu diberikan muatan kearifan budaya lokal. Hal ini sesuai dengan pernyataan dari Munandar et al. (2018, hlm. 153) yang menyatakan bahwa pelestarian kearifan lokal perlu adanya aliterasi, tidak hanya dengan pengolahan atau pembuatan produk saja. 
Siswa sebagai penerus generasi perlu mempelajari budaya Indonesia, dan untuk mempelajarinya perlu dikembangkan dalam buku bacaan siswa. Kearifan budaya lokal memiliki manfaat untuk merefleksikan nilai-nilai budaya dan berperan serta dalam membentuk karakter bangsa. Damayanti, Dewi, \& Akhlis dalam Humaida, Louisa, \& Lestari (2018, hlm. 30) menyatakan bahwa kearifan lokal adalah ciri khas etika dan nilai budaya dalam komunitas lokal yang diturunkan dari generasi ke generasi.

Rachmadiyanti (2017, hlm. 206) menyatakan bahwa kearifan lokal adalah nilai-nilai kebaikan yang senantiasa dijaga, diterapkan, dan dipercaya keberlangsungannya secara turuntemurun oleh sekelompok orang sebagai bentuk kebijaksanaan di wilayah tertentu. Senada dengan itu Soedigyo dalam Dahliani, Soemarno, \& Setijanti (2015, hlm. 159) membedakan kearifan lokal dalam dua bentuk, pertama berwujud, yaitu kearifan lokal yang terkandung dalam bentuk tulisan dan bangunan. Kedua tidak berwujud, yaitu pengetahuan lokal tidak berwujud dapat ditemukan dalam saran yang ada disampaikan secara lisan dan turun-temurun melalui lagu, balada yang berisi ajaran tradisional.

Kearifan lokal dilestarikan tentu mempunyai maksud tertentu. Hal ini sesuai dengan pendapat Sumarmi \& Amirudin dalam Tinja et al. (2017, hlm. 1258) yang menjelaskan fungsi kearifan lokal di antaranya, yaitu: (1) sebagai identitas suatu komunitas tertentu, (2) sebagai perekat antar warga, antar agama, dan kepercayaan, (3) memberikan warna kesatuan dalam sebuah komunitas, (4) mengubah pola pikir dan hubungan timbal balik atas kebudayaan yang dimiliki, (5) terbangunnya kebersamaan. Kearifan lokal merupakan bagian dari masyarakat yang telah mengakar dan tidak dapat dihilangkan. Tinja, Towaf, \& Hariyono (2017, hlm. 1258) menjelaskan bahwa kearifan lokal merupakan kebiasaan- kebiasaan yang mengandung unsur nilai budaya yang tinggi yang tertanam kuat dalam kehidupan masyarakat tertentu.

Kebiasaan-kebiasaan yang tertanam pada kehidupan masyarakat memiliki nilainilai budaya tertentu. Hal ini sebagaimana dikemukakan oleh Nadlir dalam Ratnasari, Suryana, \& Apriliya (2018, hlm. 275) yang menyatakan bahwa kearifan lokal dapat dipahami sebagai pandangan-pandangan, nilai-nilai, gagasan-gagasan setempat yang bersifat bijaksana, bernilai baik, penuh kearifan, yang tertanam dan diikuti oleh masyarakatnya. Nilai-nilai budaya inilah yang perlu dilestarikan melalui generasi muda. Kearifan lokal dalam pendidikan penting untuk meningkatkan ketahanan nasional sebagai sebuah bangsa Sutriyati, Mulawarman, \& Hudiyono (2019, hlm. 40).

Buku bacaan akan lebih mudah digunakan untuk memperkenalkan budaya Indonesia kepada siswa. Oleh karena itu, untuk pengenalannya diperlukan buku bacaan guna menunjang pengetahuan siswa mengenai kearifan lokal di Indonesia. Melalui buku bacaan, siswa akan menangkap hal-hal yang ingin disampaikan penulis mengenai kearifan lokal melalui sebuah cerita. Pemberian pengetahuan yang berkaitan dengan budaya lokal menurut Lestari et al. (2019, hlm. 224) akan lebih mudah jika diterapkan dalam sastra anak. Sastra anak tersebut diwujudkan dalam buku cerita anak. Menurutnya, sastra anak adalah sastra yang dapat ditanggap dan dipahami oleh anak secara emosional psikologis dan pada umumnya berdasarkan fakta yang konkret dan mudah diimajinasikan. Sastra anak tersebut diwujudkan dalam buku cerita anak.

Kegiatan literasi sudah menjadi kegiatan yang biasa dilakukan di sekolahsekolah. Siswa perlu mengetahui dan mempelajari budaya di Indonesia seperti kebiasaan, tradisi, bahasa, agama, nilainilai, moral, dan lain sebagainya. Kearifan lokal juga bermanfaat sebagai sebuah 
identitas dan menjadi sebuah keunikan yang memiliki ciri khas yang membedakan antara daerah yang satu dengan yang lainnya. Melalui generasi penerus, kearifan budaya lokal di Indonesia akan dikenal meskipun zaman sudah berkembang.

Buku bacaan siswa yang memuat kearifan lokal dapat digunakan sebagai salah satu cara agar siswa mengenali budaya di Indonesia. Hal ini selaras dengan pendapat Tosun dan Taskesenligil dalam Setiawan, Innatesari, Sabtiawan, \& Sudarmin (2017, hlm. 51) yang menyatakan bahwa peserta didik yang telah memiliki pengalaman belajar terkait dengan kearifan lokal akan cenderung mendapatkan peningkatan kognitif karena mereka lebih termotivasi.

Buku bacaan yang diberikan kepada siswa perlu diperhatikan pula standar konteksnya, Pusat Perbukuan dalam Bakti et al. (2018, hlm. 235), yaitu kemenarikan, kesesuaian, dan kemudahan membaca. Sedangkan, menurut Mintowati dalam Bakti, Apriliya, \& Hidayat (2018, hlm. 235) ada tiga hal kriteria standar konteks buku bacaan untuk siswa yang perlu diperhatikan dalam pemilihan bacaan, yaitu tingkat konteks budaya, kesukaran dan kemenarikan bagi siswa. Suatu bacaan anak-anak harus sesuai dengan alam hidup anak-anak pula. Bacaan anak-anak tidak selalu berupa cerita fiksi tetapi dapat juga berasal dari nonfiksi atau fakta. Usia anakanak suka buku bacaan yang di dalamnya terdapat cerita dan gambar yang menarik (Setiawati, Rusilowati, \& Khumaedi, 2013, hlm. 129).

Ediasari dalam Yetti (2009, hlm. 21) menyatakan bahwa pada usia antara 2-6 tahun, anak-anak suka pada buku bacaan yang isinya didominasi oleh gambargambar yang nyata. Pada usia 7 tahun anak menyukai buku yang didominasi oleh gambar-gambar dengan kata-kata yang sederhana dan mudah dibaca, dan bentuk tulisan yang besar-besar. Pada usia 8-9 tahun, anak-anak suka pada buku bacaan yang komposisi tulisan dan gambarnya seimbang. Kemudian pada usia 10-12 tahun anak lebih menyukai buku dengan tulisan yang lebih banyak daripada gambar. Pada usia ini anak dapat menemukan intisari dari buku bacaan karena kemampuan berpikir anak mulai berkembang.

Imajinasi anak akan berkembang lebih luas jika didukung dengan adanya gambar pada suatu bacaan anak. Media gambar dapat mempermudah pemahaman anak dalam memahami isi cerita dan dapat memperkuat ingatan anak (Afnida, Fakhriah, \& Fitriani, 2016, hlm. 53).

Sebuah buku di dalamnya harus memuat tema yang mendidik, yang dapat diambil nilai moralnya, baik moral sosial, kepribadian, maupun religiusnya. Pada dasarnya buku cerita merupakan salah satu buku teks bacaan yang dibuat untuk proses pembelajaran anak (Halim \& Munthe, 2019, hlm. 204).

Menurut Suwignyo \& Harsiati dalam Hermansyah (2017, hlm. 18) cerita anak dapat diambil pesan atau nilai-nilai moralnya baik yang berasal dari dalam negeri maupun dari luar negeri. Nilai-nilai moral dalam karya sastra dapat berupa nilai moral kepribadian, nilai moral sosial, dan nilai moral religius.

Untuk mengembangkan buku bacaan, peran Kemdikbud dalam penerbitan buku-buku bacaan, yaitu dengan bekerja sama dengan Ikatan Penerbit Indonesia (IKAPI) dan Perpustakaan Nasional RI. Program penerbitan buku untuk siswa, yaitu dengan program Gerakan Sekolah Menulis Buku (GSMB) bersama Gerakan Literasi Nasional Publik Indonesia dan Balai Bahasa Jawa Tengah meliputi kegiatan lomba menulis puisi secara serentak, penerbitan buku, festival literasi, bengkel kerja (workshop), seminar nasional, penganugerahan pemenang, dan aksi donasi "Semangat Sejuta Buku: Untuk Indonesiaku".

Berdasarkan uraian di atas, maka masalah yang menjadi fokus penelitian, yaitu muatan kearifan lokal yang terdapat 
pada buku bacaan siswa terbitan Kemdikbud. Penelitian ini bertujuan untuk mengidentifikasi muatan kearifan lokal pada buku bacaan siswa terbitan Kemdikbud. Manfaat dari penelitian ini, yaitu memberikan informasi, wawasan, dan pengetahuan mengenai muatan kearifan lokal pada buku bacaan siswa terbitan Kemdikbud.

Buku bacaan Kenara Anak Suku Gayo dan Kain Kulit Kayu Dei merupakan buku bacaan siswa terbitan Kemdikbud yang akan dianalisis muatan kearifan lokal di dalamnya. Penelitian yang juga membahas mengenai buku bacaan siswa yang memuat kearifan lokal juga dikaji oleh beberapa pengkaji. Munandar et al. (2018) tentang penggunaan buku cerita anak berbasis kearifan lokal Mendong Tasikmalaya; Bakti et al. (2018) tentang buku cerita anak berbasis kearifan lokal Kelom Geulis Tasikmalaya; Ratnasari et al. (2018) tentang buku cerita anak berbasis kearifan lokal Payung Geulis Tasikmalaya

\section{B. METODE}

Jenis penelitian ini adalah penelitian deskriptif kualitatif. Metode deskriptif kualitatif digunakan untuk mendeskripsikan muatan kearifan lokal yang terdapat dalam buku bacaan siswa terbitan Kemdikbud. Data dari penelitian ini adalah buku bacaan siswa terbitan Kemdikbud yang memuat kearifan lokal. Sumber data penelitian adalah arsip atau dokumen berupa buku bacaan siswa terbitan Kemdikbud yang memuat kearifan lokal. Teknik pengumpulan data menggunakan teknik simak dan catat, yakni peneliti membaca buku bacaan Kenara Anak. Suku Gayo dan Kain Kulit Kayu Dei terbitan Kemdikbud secara teliti untuk menentukan muatan kearifan lokal, kemudian mencatat dan menganalisis bacaan yang memuat kearifan lokal. Teknik analisis data menggunakan analisis mengalir yang meliputi tiga komponen, yaitu reduksi data, penyajian data, dan penarikan kesimpulan.
Langkah-langkah dalam analisis mengalir dapat dilihat pada gambar berikut.

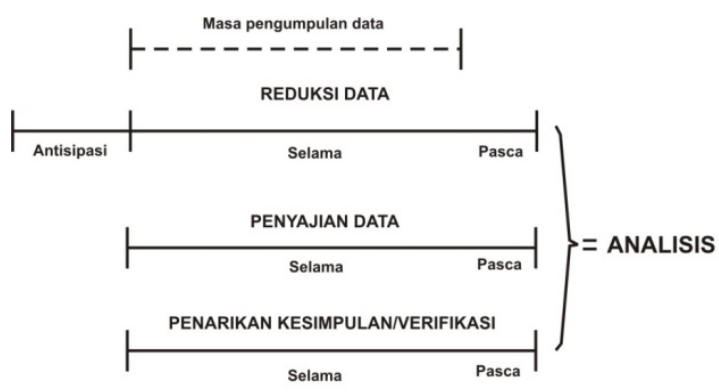

Gambar 1. Komponen-Komponen Analisis Mengalir

(Miles \& Huberman, 1994, hlm. 10)

\section{Reduksi data}

Pada proses ini peneliti merangkum dan memilih data yang dianggap pokok serta difokuskan sesuai dengan fokus penelitian. Dalam hal ini peneliti merangkum dan memilih data yang memuat kearifan lokal pada buku bacaan siswa terbitan Kemdikbud yang berjudul Kain Kulit Kayu Dei dan Kenara Anak Suku Gayo.

\section{Penyajian data}

Setelah data direduksi, langkah selanjutnya, yaitu menyajikan data. Data yang disajikan dalam penelitian ini merupakan data yang sebelumnya sudah dianalisis, namun masih berupa catatan. Data dalam penelitian yang diperoleh berupa kata atau kalimat yang memuat kearifan lokal dianalisis dan digolongkan ke dalam lima muatan, diantaranya budaya, norma, etika, kepercayaan, dan adat istiadat.

\section{Penarikan kesimpulan}

Setelah diperoleh data dan dianalisis serta digolongkan ke dalam muatan kearifan lokal, maka dapat ditarik kesimpulan dari penelitian tersebut. Kata atau kalimat manakah yang memuat kearifan lokal pada buku bacaan siswa terbitan Kemdikbud tersebut. 


\section{PEMBAHASAN}

Penelitian ini dilakukan pada dua buku bacaan siswa terbitan Kemdikbud yang memuat kearifan lokal dengan judul Kain Kulit Kayu Dei karya St. Rahmah dan Kenara Anak Suku Gayo karya Rismawati.

Bentuk-bentuk kearifan lokal yang ditemukan dalam analisis buku bacaan siswa Kenara Anak. Suku Gayo dan Kain Kulit Kayu Dei ada lima analisis. Keenam bentuk analisis tersebut sebagai berikut.

\section{Budaya}

Budaya, yaitu cara hidup yang berkembang dan dimiliki bersama oleh sekelompok orang dan diwariskan dari generasi ke generasi.

Nilai kearifan lokal pada buku bacaan Kenara Anak Suku Gayo terdapat pada data berikut.

Data 1

"Aku anak suku Gayo, Gayo Lues." (Buku bacaan Kenara Anak Suku Gayo)

Data 2

"Suku Gayo adalah suku yang fenomenal dengan dua warisan dunia yang dimilikinya, yaitu Gunung Leuser dan Tari Saman."

(Buku bacaan Kenara Anak Suku Gayo)

Data 3

"Pakaian adat suku Gayo disebut dengan kerawang. Kerawang memiliki corak dan jenis yang berbeda-beda."

(Buku bacaan Kenara Anak Suku Gayo)

\section{DATA 4}

"Rumah adat suku Gayo disebut dengan umahpitu ruang yang berarti rumah tujuh ruang."

(Buku bacaan Kenara Anak Suku Gayo)

Data 5

"Dalam masyarakat suku Gayo, tarian yang sangat populer bahkan sudah diakui sebagai warisan dunia adalah tari Saman.
Pada umumnya tari Saman dipasangkan dengan tari Bines."

(Buku bacaan Kenara Anak Suku Gayo)

Kutipan data 1 sampai 5 menggambarkan keberadaan suku Gayo. Hal ini dijelaskan dengan adanya anak yang berasal dari suku Gayo, warisan yang dimiliki suku Gayo, serta pakaian, rumah adat, dan tarian suku Gayo. Nilai yang terkandung dalam kutipan tersebut, yaitu nilai budaya dalam sebuah suku, dalam kutipan tersebut, yaitu suku Gayo.

Data 6

"Canang adalah alat musik pukul yang sangat populer dalam kehidupan masyarakat Gayo." (Canang adalah gong kecil).

(Buku bacaan Kenara Anak Suku Gayo)

Data 7

"Alat musik masyarakat suku Gayo yang khas lainnya adalah popo." (Popo adalah alat musik tiup).

(Buku bacaan Kenara Anak Suku Gayo)

Data 8

"Kecapi a masyarakat Gayo ini terbuat dari bambu betung. Dalam suku Gayo alat ini bernama Teganing."

(Buku bacaan Kenara Anak Suku Gayo)

Data 9

"Suling atau biasa disebut seruling merupakan alat musik yang khas dalam masyarakat suku Gayo. Seruling ini dibuat dari bambu."

(Buku bacaan Kenara Anak Suku Gayo)

Kutipan data 6 sampai 9 menggambarkan alat musik khas suku Gayo. Hal ini dijelaskan dengan adanya musik canang, popo, teganing, dan suling yang merupakan alat musik masyarakat khas suku Gayo. Nilai yang terkandung dalam kutipan tersebut, yaitu nilai budaya yang berupa alat musik. 
Data 10

"Kata ine masyarakat Gayo memiliki kerajinan tangan yang dibuat langsung oleh masyarakat suku Gayo. Kerajinan tangan tersebut banyak yang berbentuk anyaman. Biasanya anyaman masyarakat Gayo berasal dari daun pandan, dan rotan."

(Buku bacaan Kenara Anak Suku Gayo)

Kutipan data 10 menggambarkan kerajinan khas masyarakat suku Gayo. Hal ini dijelaskan dengan adanya kerajinan tangan masyarakat suku Gayo yang berupa anyaman dari daun pandan dan rotan. Nilai yang terkandung dalam kutipan tersebut, yaitu nilai budaya berupa kerajinan tangan khas masyarakat suku Gayo.

\section{Data 11}

"Kero tum adalah makanan khas masyarakat Gayo. Kero tum ini hanyalah nasi putih yang dibungkus dengan daun pisang." (Buku bacaan Kenara Anak Suku Gayo)

Data 12

"Masang jaing adalah jenis masakan dengan paduan rasa pedas dan asam. Makanan ini adalah bentuk gulai yang biasanya memiliki bahan dasar ikan."

(Buku bacaan Kenara Anak Suku Gayo)

Data 13

"Pengat adalah sejenis makanan yang dimasak hingga kuahnya dikeringkan. Bahan dasar pengat adalah ikan."

(Buku bacaan Kenara Anak. Suku Gayo)

Data 14

"Cicah adalah makanan yang dibuat dengan metode dilumatkan. Masakan ini dapat berbahan buah, dapat juga berbahan ikan, sayuran, dan bahkan daging."

(Buku bacaan Kenara Anak Suku Gayo)

Data 15

"Cepra adalah jenis makanan yang serupa bubur ayam. Namun, biasanya masakan ini dibuat secara bersamaan antara beras dan ayam."

(Buku bacaan Kenara Anak Suku Gayo)

Data 16

"Gutel adalah makanan yang terbuat dari gula merah, kelapa, dan tepung beras." (Buku bacaan Kenara Anak Suku Gayo)

Kutipan data 11 sampai 16 menggambarkan makanan khas masyarakat suku Gayo. Hal ini dapat dilihat dari kutipan penjelasan macammacam makanan khas suku Gayo, yaitu kero tum, masang jaing, pengat, cicah, cepra, dan gutel. Nilai yang terkandung dalam kutipan tersebut, yaitu nilai budaya berupa makanan khas masyarakat suku Gayo.

Nilai kearifan lokal pada buku bacaan Kain Kulit Kayu Dei terdapat pada data berikut.

Data 17

"Desa Bolapapu adalah salah satu desa yang masih membudayakan pakaian yang terbuat dari kain kulit kayu atau yang biasa disebut dengan Kumpe atau Mbesa." (Buku bacaan Kain Kulit Kayu Dei)

Data 18

"Nenek Ola tidak ingin kekayaan budaya yang telah diwariskan oleh nenek moyang mereka tergerus oleh peradaban."

(Buku bacaan Kain Kulit Kayu Dei)

Data 19

"Bagi Nenek Ola, budaya harus dijaga dan dihormati serta dilestarikan agar tidak hilang dan dapat menjadi warisan kepada anak cucu kelak."

(Buku bacaan Kain Kulit Kayu Dei)

Data 20

"Salah satu langkah untuk mempertahankan budaya mereka adalah terus mempertahankan keberadaan kain kulit kayu tersebut."

(Buku bacaan Kain Kulit Kayu Deı) 
Kutipan data 17 sampai 20 menggambarkan sikap Nenek Ola yang ingin mempertahankan kebudayaan agar tidak hilang dengan adanya perkembangan zaman. Hal ini dapat dibuktikan dengan cara mempertahankan keberadaan kain kulit kayu yang merupakan kain khas masyarakat Sulawesi Tengah, khususnya desa Bolapapu yang masih membudayakan pakaian yang biasa disebut dengan Kumpe atau Mbesa tersebut.

Data 21

"Ada beberapa peralatan yang digunakan dalam proses pembuatan kain kulit kayu, antara lain, tatua, peboba, batu ike, kura tanah, banga nngkewalu, dan taono."

(Buku bacaan Kain Kulit Kayu Deı)

Data 22

"Tatua adalah landasan yang terbuat dari kayu untuk tempat memukul kulit kayu." (Buku bacaan Kain Kulit Kayu Dei)

Data 23

"Pepoba atau pola terbuat dari potongan kayu enau dan terdiri atas dua bagian, tempat pemukul dan pegangan. Alat ini berfungsi untuk menyatukan serat-serat kulit kayu agar menjadi lembut dan mudah diproses."

(Buku bacaan Kain Kulit Kayu Deı)

Data 24

"Batu Ike terbuat dari batu jenis tertentu, dibentuk lebar dengan sisi yang dibuat beralur-alur. Pada bagian sisi yang lebar dibentuk cekung untuk meletakkan rotan. Rotan tersebut akan berfungsi sebagai pegangan."

(Buku bacaan Kain Kulit Kayu Deı)

Data 25

"Kura tanah digunakan untuk merebus serat kulit kayu sebelum diproses agar menghasilkan kain yang berkualitas baik." (Buku bacaan Kain Kulit Kayu Deı)
Data 26

"Banga Ngkewalu digunakan sebagai tempat menyimpan air untuk menyiram kulit kayu yang sedang dalam proses pembuatan dengan maksud agar kulit kayu tetap basah sehingga mudah menyatukan setiap potongan."

(Buku bacaan Kain Kulit Kayu Deı)

\section{Data 27}

"Taono adalah benda sejenis parang yang digunakan untuk menebang pohon dan tangkai pohon beringin."

(Buku bacaan Kain Kulit Kayu Deı)

Data 28

"Abu dapur berfungsi untuk mempermudah proses pembusukan kayu, menetralisasi jamur, dan menetralisasi bau."

(Buku bacaan Kain Kulit Kayu Deı)

Data 29

"Air juga dibutuhkan untuk merebus kain kulit kayu yang diperam lalu dimasak dengan abu dapur yang berfungsi sebagai pelembap selama proses pembuatan kain kulit kayu berlangsung."

(Buku bacaan Kain Kulit Kayu Dei)

\section{Data 30}

"Ula Vua yakni sejenis pohon yang buahnya berwarna merah muda yang digunakan sebagai pewarna dan pengawet pakaian, lumpur yang digunakan sebagai pewarna untuk mendapatkan warna hitam dan cokelat."

(Buku bacaan Kain Kulit Kayu Deı)

\section{Data 31}

"Kayu Lehutu adalah bahan pewarna untuk warna cokelat kemerah-merahan, dan getah pohon langsat digunakan agar lebih tahan (tidak luntur)."

(Buku bacaan Kain Kulit Kayu Deı) 
Data 32

"Rumput munte digunakan agar kain berbau wangi."

(Buku bacaan Kain Kulit Kayu Dei)

Kutipan data 21 hingga 32 menggambarkan peralatan yang digunakan dalam proses pembuatan kain kulit kayu. Pembuatan kain kulit kayu membutuhkan berbagai macam peralatan yang telah disebutkan serta dijelaskan kegunaannya. Nilai yang terkandung dalam kutipankutipan di atas, yaitu nilai budaya dalam proses pembuatan kain kulit kayu yang menggunakan alat dan bahan di sekitar kita.

\section{Norma}

Norma adalah petunjuk tingkah laku yang harus dilakukan dan tidak boleh dilakukan dalam kehidupan sehari-hari, dan disertai sanksi.

Nilai kearifan lokal pada buku bacaan Kenara Anak Suku Gayo terdapat pada data berikut.

Data 33

"Serinen sebet diartikan semacam sahabat karib, yang akan terikat sampai seumur hidup sehingga kalau sudah terikat sebagai serinen sebet, ada hal-hal yang harus diemban."

(Buku bacaan Kenara Anak Suku Gayo)

Data 34

"Perannya mirip seperti saudara kandung, dan biasanya jika sudah terjalin serinen sebet anak-anak mereka pun tidak diizinkan menikah."

(Buku bacaan Kenara Anak Suku Gayo)

Kutipan data 33 dan 34 menggambarkan perilaku masyarakat suku Gayo pada kekerabatan serinen sebet dalam acara bejamu saman, saat acara bejamu saman akan terjalin kekerabatan baru yang berakibat pada anak cucunya tidak boleh menikah karena dianggap sudah satu keluarga. Nilai yang terkandung dalam kutipan tersebut, yaitu nilai norma dalam acara bejamu saman yang harus dilakukan ketika sudah menemukan serinen sebet atau sahabat karib pada acara tersebut.

\section{Etika}

Etika adalah tentang apa yang baik dan apa yang buruk dan tentang hak dan kewajiban dalam berperilaku.

Nilai kearifan lokal pada buku bacaan Kenara Anak Suku Gayo terdapat pada data berikut.

Data 35

"Kata ineku jika urang Gayo bertemu sesama urang Gayo, mereka akan menggunakan bahasa Gayo."

(Buku bacaan Kenara Anak Suku Gayo)

Kutipan data 35 menggambarkan kebiasaan masyarakat suku Gayo. Jika bertemu dengan sesama masyarakat suku Gayo maka mereka akan menggunakan bahasa Gayo. Kebiasaan tersebut merupakan etika penggunaan bahasa dalam suku Gayo.

Data 36

"Kuru adalah bentuk kekerabatan berdasarkan garis keturunan."

(Buku bacaan Kenara Anak Suku Gayo)

Data 37

"Jika satu orang dari kurunya mengalami musibah, anggota kuru akan memberi bantuan. Lalu jika ada yang mengadakan pesta, anggota kuru akan bekerja tanpa kenal lelah."

(Buku bacaan Kenara Anak Suku Gayo)

Kutipan data 36 dan 37 menggambarkan perilaku baik masyarakat suku Gayo terhadap kerabatnya. Jika salah satu kerabat mengalami musibah, maka kerabat lainnya memberi bantuan dan jika kerabat mengadakan hajatan, maka kerabat lainnya akan membantu. Kebiasaan tersebut merupakan sebuah etika dalam kekerabatan. 
Data 38

"Tutur (sapaan) dalam suku Gayo sangat terikat. Tidak boleh sembarangan menyapa orang lain.”

(Buku bacaan Kenara Anak Suku Gayo)

Data 39

"Walaupun umurnya lebih tua, kalau memang dalam tuturnya harus disapa adik, ya tetap adik."”

(Buku bacaan Kenara Anak Suku Gayo)

Kutipan data 38 dan 39 menggambarkan perilaku masyarakat suku Gayo melalui tutur atau sapaan. Dalam aturannya, setiap masyarakat tidak boleh sembarangan menyapa orang lain, karena semua sudah diatur berdasarkan garis keturunan. Meskipun umurnya lebih tua, kalau dalam tuturnya harus diapa adik ya tetap adik. Begitu sebaliknya, meskipun lebih muda, jika dalam tuturnya harus disapa kakak atau abang ya tetap menyapanya kakak atau abang. Hal tersebut termasuk etika sapaan sesuai garis keturunan.

\section{Kepercayaan}

Kepercayaan, yaitu keyakinan terhadap sesuatu bahwa yang dipercaya itu nyata dan benar.

Nilai kearifan lokal pada buku bacaan Kenara Anak Suku Gayo terdapat pada data berikut.

Data 40

"Dimakan atau tidaknya makanan yang dibawa tersebut adalah sebagai simbol direstui atau tidaknya acara yang akan dilakukan."

(Buku bacaan Kenara Anak Suku Gayo)

Kutipan 40 menggambarkan perilaku masyarakat suku Gayo yang membawakan makanan kepada pamannya sebagai simbol direstui atau tidaknya acara yang akan dilakukan. Acara ini dinamakan sebagai ngude, yaitu acara yang dilakukan sebelum seseorang menikah atau melakukan sunat rasul. Mereka mendatangi rumah pamannya untuk memohon doa restu. Nilai yang terkandung dalam kutipan tersebut, yaitu nilai kepercayaan pada restu atau tidak seorang paman berdasarkan dimakan atau tidaknya makanan yang dibawa tersebut.

\section{Data 41}

"Banyaknya uang yang dicucukean di atas kepala menggambarkan kesejahteraan kehidupan pamannya."

(Buku bacaan Kenara Anak Suku Gayo)

Kutipan 41 menggambarkan perilaku masyarakat suku Gayo yang setelah mendapat restu dari paman ia akan menunggangi kuda bak seorang raja. Lehernya diberi kalungan bunga dan kepalanya dihiasi lidi dengan tempelan uang. Banyaknya uang yang ditempelkan di kepala menggambarkan kesejahteraan kehidupan pamannya. Nilai yang terkandung dalam kutipan tersebut, yaitu nilai kepercayaan pada kesejahteraan pamannya berdasarkan banyaknya uang yang dicucukekan di atas kepala anak tersebut.

\section{Data 42}

"Meski dipercaya dapat menjadi tolak bala. Namun, tawar kampung sangat langka dilakukan masyarakat Gayo Lues."

(Buku bacaan Kenara Anak Suku Gayo)

Data 43

"Dalam kenduri itu masyarakat akan memanjatkan puji syukur kepada Tuhan, memohon kesejahteraan, kesejukan serta kesuburan lahan pertanian agar lahan tersebut bermanfaat bagi masyarakat." (Buku bacaan Kenara Anak Suku Gayo)

Kutipan data 42 dan 43 menggambarkan kepercayaan masyarakat suku Gayo pada acara tawar kampung yang dapat menjadi tolak bala. Namun, tawar kampung sangat langka dilakukan 
masyarakat Gayo Lues karena membutuhkan biaya yang sangat besar dalam pelaksanaannya. Masyarakat suku Gayo juga memanjatkan puji syukur kepada Tuhan, memohon kesejahteraan, kesejukan, dan kesuburan lahan pertanian agar bermanfaat bagi masyarakat.

Data 44

"Sesube adalah salah satu makanan yang mengandung nilai mistis. Masyarakat percaya makanan ini mampu menolak bala."

(Buku bacaan Kenara Anak Suku Gayo)

Kutipan data 44 menggambarkan kepercayaan masyarakat suku Gayo pada sasube, yaitu sala satu makanan yang dianggap masyarakat suku Gayo mengandung nilai mistis dan dapat menjadi tolak bala.

Nilai kearifan lokal pada buku bacaan Kain Kulit Kayu Dei terdapat pada data berikut.

Data 45

"Menurut kepercayaan dalam masyarakat Kulawi, kematian merupakan proses peralihan dari suatu tempat ke tempat yang lain.”

(Buku bacaan Kain Kulit Kayu Deı)

Kutipan data 45 menggambarkan kepercayaan dalam masyarakat Kulawi. Menurut masyarakat Kulawi, kematian merupakan proses peralihan dari suatu tempat ke tempat yang lain. Kutipan tersebut mengandung nilai kepercayaan terhadap proses kematian.

Data 46

"Orang Kulawi meyakini bahwa roh akan hidup selama-lamanya."

(Buku bacaan Kain Kulit Kayu Dei)

Kutipan data 46 menggambarkan kepercayaan orang Kulawi bahwa roh akan hidup selama-lamanya. Hal ini mengandung nilai kepercayaan terhadap adanya roh yang terus hidup.

Data 47

"Upacara ini dilakukan agar orang yang telah meninggal memperoleh perlindungan dari para kampua $i$ tana 'penguasa bumi' dan kampuaa $i$ langi 'penguasa langit' dan rohnya tidak mengganggu orang yang masih hidup."

(Buku bacaan Kain Kulit Kayu Dei)

Kutipan data 47 menggambarkan perilaku orang Kulawi yang melakukan upacara terhadap orang yang telah meninggal agar mendapat perlindungan dan rohnya tidak mengganggu orang yang masih hidup. Kutipan tersebut mengandung nilai kepercayaan terhadap adanya penguasa bumi dan penguasa langit.

Data 48

"Maksud upacara rakeho adalah untuk mencari keselamatan dan kebahagiaan." (Buku bacaan Kain Kulit Kayu Dei)

Kutipan data 48 menggambarkan kepercayaan orang Kulawi terhadap upacara rakeho. Upacara tersebut dimaksudkan agar masyarakat Kulawi diberikan keselamatan dan kebahagiaan.

\section{Adat Istiadat}

Adat istiadat adalah tata kelakuan secara turun temurun sebagai warisan sehingga hubungan dengan pola perilaku masyarakat terjalin kuat.

Nilai kearifan lokal pada buku bacaan Kenara Anak Suku Gayo terdapat pada data berikut.

Data 49

"Bejamu saman adalah sebuah pesta adat yang dilakukan seusai panen padi atau seusai hari raya."

(Buku bacaan Kenara Anak Suku Gayo) 
Data 50

"Bejamu saman adalah proses tanding saman antara satu desa dengan desa yang lain dilakukan selama satu hari, satu malam, atau selama dua hari dua malam." (Buku bacaan Kenara Anak Suku Gayo)

Kutipan data 49 dan 50 termasuk dalam bentuk kearifan lokal adat-istiadat yang digambarkan dalam acara bejamu saman. Pesta ini biasa dilakukan satu tahun sekali, dan dilaksanakan bergiliran dengan desa lainnya. Bejamu saman merupakan proses tanding saman yang akan berlanjut dengan terbentuknya kekerabatan baru yang disebut serinen sebet.

Data 51

"Ngude adalah pesta perkawinan atau sunatan yang menggunakan kuda sebagai media pelaksanaannya."

(Buku bacaan Kenara Anak Suku Gayo)

Data 52

"Biasanya ngude dilakukan sebelum seseorang menikah, atau disunat rasul, dia akan mendatangi rumah pamannya (saudara laki-laki ibu) untuk memohon doa restu."

(Buku bacaan Kenara Anak Suku Gayo)

Data 53

"Untuk mendatangi rumah paman, biasanya yang akan disunat ditemani oleh beberapa orang tua di kampung membawa aneka makanan khas, dan kero tum."

(Buku bacaan Kenara Anak Suku Gayo)

Kutipan data 51 hingga 53 termasuk dalam bentuk kearifan lokal adat istiadat yang digambarkan dalam acara ngude. Dalam acara ini, kuda digunakan sebagai media pelaksanaannya. Ngude dilakukan sebelum seseorang menikah atau disunat rasul yang akan mendatangi rumah pamannya untuk memohon doa restu dengan membawa aneka makanan khas dan kero tum.
DATA 54

"Tawar Kampung merupakan serangkaian acara adat yang dapat memberikan kesejukan suasana dalam masyarakat kampung." (Buku bacaan Kenara Anak Suku Gayo)

Data 55

"Daging kerbau yang sudah masak akan disajikan untuk acara kenduri yang digelar secara bersama."

(Buku bacaan Kenara Anak Suku Gayo)

Data 56

"Tawar kampung, selain memiliki nilai spiritual juga telah menjadi budaya bagi masyarakat suku Gayo."

(Buku bacaan Kenara Anak Suku Gayo)

Kutipan data 54 hingga 56 termasuk dalam bentuk kearifan lokal adat istiadat yang digambarkan dalam acara tawar kampung dan acara kenduri yang digelar secara bersamaan. Biasanya melakukan pemotongan hewan kerbau kemudian dibawa berkeliling kampung dengan diiringi berbagai ritual, nyanyian, dan musik tradisional.

\section{Data 57}

"Biasanya makanan ini dibuat jika seseorang akan mengantarkan nasi untuk besan, mertua, atau paman.” (Kero tum).

(Buku bacaan Kenara Anak Suku Gayo)

Data 58

"Makanan ini tidak setiap waktu dibuat. Biasanya dibuat pada masa tertentu saja, misalnya pada musim panen atau saat ada bencana."

(Buku bacaan Kenara Anak Suku Gayo)

Kutipan data 57 dan 58 termasuk dalam bentuk kearifan lokal adat istiadat yang digambarkan dalam pembuatan kero tum. Makanan ini biasa dibuat untuk mengantarkan nasi kepada besan, mertua, atau paman atau pada musim panen atau saat bencana. 
Data 59

"Cepra biasanya dihidangkan pada acara khusus seperti pesta, sunatan rasul, pesta perkawinan, dan bahkan pada pesta panen."

(Buku bacaan Kenara Anak Suku Gayo)

Kutipan data 59 termasuk dalam bentuk kearifan lokal adat istiadat yang digambarkan dalam makanan cepra dan biasa disajikan untuk pesta, sunatan rasul, maupun acara khusus lainnya. Cepra merupakan makanan yang serupa dengan bubur ayam.

Nilai kearifan lokal pada buku bacaan Kain Kulit Kayu Dei terdapat pada data berikut.

Data 60

"Tradisi pembuatan kulit kayu ini juga dimanfaatkan sebagai perlengkapan upacara adat."

(Buku bacaan Kain Kulit Kayu Dei)

Kutipan data 60 termasuk dalam bentuk kearifan lokal adat istiadat yang digambarkan dalam tradisi pembuatan kulit kayu yang dimanfaatkan sebagai perlengkapan upacara adat.

Data 61

"Pengantaran jenazah Nenek Ola dilakukan dengan upacara popetana, yakni bentuk upacara yang dilakukan oleh masyarakat Kulawi ke tempat nenek untuk dikebumikan."

(Buku bacaan Kain Kulit Kayu Deı)

Kutipan data 61 termasuk dalam bentuk kearifan lokal adat istiadat yang digambarkan dalam upacara popetana dalam rangka pengantaran jenazah. Upacara ini dilakukan masyarakat Kulawi ke tempat seseorang untuk dikebumikan.

Data 62

"Upacara rakeho adalah salah satu jenis upacara yang diadakan oleh orang Kulawi untuk menyambut peralihan seorang pria dari masa remaja ke masa dewasa."

(Buku bacaan Kain Kulit Kayu Deı)

Data 63

"Semua orang yang menghadiri upacara rukeho mengenakan busana adat."

(Buku bacaan Kain Kulit Kayu Deı)

Data 64

"Prosesi pemakaian baju dan penyuapan makanan diadakan di dalam rumah. Prosesi meratakan gigi diadakan di tempattempat tertentu, seperti di bawah pohon yang besar atau di sebuah rumah yang telah dikosongkan sebelumnya." (Buku bacaan Kain Kulit Kayu Dei)

Kutipan data 62 hingga 64 termasuk dalam bentuk kearifan lokal adat istiadat yang digambarkan dalam upacara rakeho. Upacara tersebut diadakan untuk menyambut peralihan seorang pria dari masa remaja ke masa dewasa. Dalam upacara ini, semua orang yang datang harus mengenakan pakaian adat. Sedangkan prosesi upacaranya dilakukan sesuai ketentuan-ketentuan tertentu.

\section{PENUTUP}

Berdasarkan hasil analisis dan pembahasan yang telah diuraikan pada bab sebelumnya, maka dapat ditarik simpulan yakni muatan kearifan lokal yang terdapat pada buku bacaan siswa yang berjudul Kenara Anak Suku Gayo ada lima muatan, diantaranya, yaitu (1) budaya, (2) moral, (3) etika, (4) kepercayaan, dan (5) adat istiadat. Sedangkan buku bacaan Kain Kulit Kayu Dei terdapat tiga muatan kearifan lokal diantaranya, (1) budaya, (2) kepercayaan, dan (3) adat istiadat.

\section{DAFTAR PUSTAKA}

Afnida, M., Fakhriah, \& Fitriani, D. (2016). Penggunaan Buku Cerita Bergambar dalam Pengembangan Bahasa Anak Pada TK A di Banda Aceh. Jurnal Ilmiah Mahasiswa 
Pendidikan Anak Usia Dini, 1(1), 5359.

https://media.neliti.com/media/pub lications/187164-ID-none.pdf

Bakti, T. R. S., Apriliya, S., \& Hidayat, S. (2018). Buku Cerita Anak Berbasis Kearifan Lokal Kelom Geulis Tasikmalaya untuk Siswa Sekolah Dasar. PEDADIDAKTIKA: Jurnal Ilmiah Pendidikan Guru Sekolah Dasar, 5(1), 232-241.

Dahliani, Soemarno, I., \& Setijanti, P. (2015). Local Wisdom in Built Environment in Globalization Era. International Journal of Education and Research, 3(6), 157-166.

Halim, D., \& Munthe, A. P. (2019). Dampak Pengembangan Buku Cerita Bergambar untuk Anak Usia Dini. Scholaria: Jurnal Pendidikan Dan Kebudayaan, 9(3), 203-216.

Hermansyah, A. K. (2017). Nilai-Nilai Kemanusiaan dalam Buku 100 Cerita Anak Pilihan dan Kesesuaiannya Sebagai Bahan Pembelajaran Sastra di SD/MI. Al Ibtida: Jurnal Pendidikan Guru MI, 4(1), 17-28. https://doi.org/10.24235/al.ibtida.s nj.v4i1.1368

Humaida, N., Louisa, V. M., \& Lestari, N. C. (2018). Characteristics of The Local Wisdom from South Borneo In Ecological Aspect. ESE International Journal, 1(2), 30-34.

Lestari, A., Hodidjah, \& Apriliya, S. (2019). Buku Cerita Anak Tentang Makanan Tradisional Nasi Tutug Oncom Khas Tasikmalaya untuk Siswa Sekolah Dasar. PEDADIDAKTIKA: Jurnal Ilmiah Pendidikan Guru Sekolah Dasar, 6(1), 223-228.

Miles, M. B., \& Huberman, A. M. (1994). An Expanded Sourcebook Qualitative Data Analysis (Second Edition). SAGE Publications.

Munandar, A., Mulyadiprana, A., \& Apriliya, S. (2018). Penggunaan Buku Cerita Anak Berbasis Kearifan Lokal
Mendong Tasikmalaya di Sekolah Dasar. PEDADIDAKTIKA: Jurnal Ilmiah Pendidikan Guru Sekolah Dasar, 5(2), 152-162.

Rachmadiyanti, P. (2017). Penguatan Pendidikan Karakter Bagi Siswa Sekolah Dasar melalui Kearifan Lokal. JPSD, 3(2), 201-214.

Ratnasari, A., Suryana, Y., \& Apriliya, S. (2018). Buku Cerita Anak Berbasis Kearifan Lokal Payung Geulis Tasikmalaya untuk Siswa SD. PEDADIDAKTIKA: Jurnal Ilmiah Pendidikan Guru Sekolah Dasar, 5(1), 274-285.

Setiawan, B., Innatesari, D. K., Sabtiawan, W. B., \& Sudarmin, S. (2017). The development of local wisdom-based natural science module to improve science literation of students. Jurnal Pendidikan IP A Indonesia, 6(1), 49-54. https://doi.org/10.15294/jpii.v6i1.9 595

Setiawati, I. K., Rusilowati, A., \& Khumaedi. (2013). Pembuatan Buku Cerita IPA yang Mengintegrasikan Materi Kebencanaan Alam untuk Meningkatkan Literasi Membaca dan Pembentukan Karakter. Jurnal Pendidikan IPA Indonesia, 2(2), 129135.

https://doi.org/10.15294/jpii.v2i2.2 713

Sutriyati, Mulawarman, W. G., \& Hudiyono, Y. (2019). Pengembangan Bahan Ajar Menulis Esai dengan Memanfaatkan Kearifan Lokal melalui Pembelajaran Berbasis Proyek (PBP) Siswa SMA. Diglosia, 2(1), 39-46. https://doi.org/10.30872/diglosia.v $2 \mathrm{i} 1.16$

Tinja, Y., Towaf, S. M., \& Hariyono. (2017). Pengembangan Bahan Ajar Tematik Berbasis Kearifan Lokal Sebagai Upaya Melestarikan Nilai Budaya Pada Siswa Sekolah Dasar. Jurnal Pendidikan, 2(9), 1257-1261.

Yetti, R. (2009). Pengaruh Keterlibatan 
Orang Tua Terhadap Minat

Membaca Anak Ditinjau dari

Pendekatan Stres Lingkungan.

PEDAGOGI | Jurnal Ilmiah Ilmu

Pendidikan, IX(1), 17-28.

http://ejournal.unp.ac.id/index.php

/pedagogi 